

Research Article

Ankara Med J, 2020;(1):57-68 // 10.5505/amj.2020.01643

\title{
DETERMINATION OF THE EFFICIENCY OF MENSTRUATION HYGIENE TRAINING GIVEN TO TRAINABLE INTELLECTUAL DISABILITY ADOLESCENT GIRLS
}

ÖĞRETİLEBILIİR ZİHİNSEL ENGELLİ KIZ ERGENLERE VERILLEN MENSTRUASYON HİJYEN EĞITTIMİNIN ETKINLİĞİNIN BELİRLENMESİ

(D) İlknur Münevver Gönenç ${ }^{1}$, (D) Nazan Çakırer Çalbayram², (D) Sebahat Altundağ³, (D) Ömür Aktaş4

${ }^{1}$ Ankara University Faculty of Nursing, Ankara

${ }^{2}$ Çanakkale Onsekiz Mart University School of Health, Department of Nursing, Çanakkale

3Pamukkale University, Denizli School of Health, Department of Nursing, Denizli

${ }^{4}$ Gazi University Hospital, Ankara

Yazışma Adresi / Correspondence:

İlknur Münevver Gönenç (e-posta: imgonenc@gmail.com)

Geliş Tarihi (Submitted): 23.10.2019 // Kabul Tarihi (Accepted): 20.02.2020



Ankara YIldırım Beyazıt University Faculty of Medicine Department of Family Medicine 


\title{
Öz
}

Amaç: Öğretilebilir zihinsel engelli kız ergenlere verilen menstruasyon hijyen eğitiminin etkinliğinin değerlendirmektir.

Materyal ve Metot: Çalışma pre-post test yarı deneysel çalışma olarak yürütüldü. Araştırma Ankara il merkezinde bir Özel Eğitim İş Uygulama Merkezinde (Okulu) bulunan öğretilebilir zihinsel engelli ergen (ÖZEE) kız öğrencilerle yapıldı. Çalışma 25 ÖZEE ile tamamlandı. Verileri "tanıtıcı bilgi formu" ve "menstruasyon beceri değerlendirme formu" aracilığıyla toplandı. Araştırmacılar tarafından katılımcılara hijyenik ped değiştirme becerisi kazandırmak için eğitim verildi. Eğitim öncesi ve sonrası kız öğrencilerin ped değiștirme becerileri izlendi. İzlemler eğitimden bir ay sonra ve altı ay sonra yapıldı. Veriler bilgisayar ortamında değerlendirildi.

Bulgular: Çalışma kapsamındaki ÖZEE yaş ortalamalarının 16,56 $\pm 1,00$ (14-18), hepsinin adet gördüğg̈ (25 kişi), adet olma durumlarının normal döngüde olduğu belirlendi. Eğitim öncesi ped değiştirme becerisi ortanca puanı 16,00 (Min: 0- Maks: 36), eğitim sonrası birinci izlemde 36,00 (Min: 22- Maks: 36), ikinci izlemde 36,00 (Min: 24- Maks: 36) olup fark istatistiksel olarak anlamlı bulundu $(\mathrm{p}<0,001)$.

Sonuç: ÖZEE'lere hemşireler tarafından video ve oyuncak bebek kullanılarak verilen eğitimin, zihinsel engelli adölesanların ped değiştirme becerilerini kazandırmada etkili bir yöntem olduğunu ortaya koymuştur.

Anahtar Kelimeler: Anahtar kelimeler, anahtar, anahtar

\begin{abstract}
Objectives: This study aimed to evaluate the efficiency of menstruation hygiene training given to trainable intellectual disability adolescent girls.

Materials and Methods: The study was conducted as a pretest-posttest quasi-experimental study. It was carried out with educable intellectual disability adolescent girls attending a Special Education and Application Center (School) located in the central county of Ankara province. The study was completed with 25 participants. Data were collected through a "personal information form" and "menstrual skills assessment form". The researchers given education to participants to gain sanitary pad replacement skills. The menstrual pad replacement skills of them were followed before and after the training. The follow-ups were extended to the first and the sixth month after the training. Data were evaluated by computer.

Results: The mean age of the participants in the study was $16.56 \pm 1.00$ (14-18). All of them had already got periods. Their menstrual process was found to be in the normal cycle. The median score for pre-interventional pad replacement skill was 16.00 (minimum: 0- maximum: 36). The post-interventional score for the first follow-up was 36.00 (minimum: 22- maximum: 36), it was 36.00 (minimum: 24- maximum: 36) in the second follow-up, and the difference was found strong evidence in support of the alternative hypothesis $(p<0.001)$.

Conclusion: It was revealed that the training given trainable intellectual disability adolescent girls by nurses by using video and dolls was an effective method for having intellectual disability adolescents gain pad replacement skills.
\end{abstract}

Keywords: Menstruation hygiene, trainable mentally retarded, adolescent, training, nursing 


\section{Introduction}

Menstruation is one of the most important events of the adolescent period. Menstrual care skills, which are necessary during the menstruation period, are life skills and are specific to women. ${ }^{1}$ The preparation of individuals for this period begins in the family and at school in the early ages of youth. A healthy individual is expected to manage her own menstrual hygiene independently within a few months at most. However, for intellectual disability adolescents, the situation is different. ${ }^{2}$

Menstruation is a challenge for intellectual disability adolescents. These individuals experience problems in noticing the start of menstruation, perineum cleaning, hand hygiene, and pad use. ${ }^{3}$ Skills retardation in intellectual disability individuals causes problems to both parents and teachers in teaching the use of pads. For this reason, this skill, which can be performed practically in daily life and is accepted as normal, is difficult to teach to intellectual disability individuals. ${ }^{4}$ The onset of menstruation for intellectual disability adolescents can affect their independence and create additional concerns for families at home, at schools, and at other settings. ${ }^{5}$ Parents often worry about the effect of pubertal development on the lives and health of their daughters with mental disabilities. ${ }^{6}$ For this reason, intellectual disability adolescents are often not taught these skills; instead, the care is given by the caregivers. Rodgers \& Lipscombe (2005) found in their study that $29 \%$ of intellectual disability women were never given the opportunity to manage their own menstrual care. This increases the dependency of these individuals, the workload of the caregivers, and the level of burnout. In addition, adolescents who have not gained necessary menstrual care skills are not sent to school in these periods, and therefore their education lives are negatively affected. ${ }^{7}$

Nurses, who are most often in touch with healthy/sick individuals, play an important role in teaching genital hygiene behaviors to intellectual disability adolescents and having them take responsibility. Nurses can help parents and teachers develop skills in these individuals. This study evaluated the effectiveness of menstrual hygiene training given by nurses. The review of the related literature revealed that there are very few studies on this subject in our country and other countries, ${ }^{4,8-11}$ and that these studies have been carried out with a limited number of individuals and educable intellectual disability individuals. IQ test results fall along the normal (bell-shaped) curve, with an average IQ of 100, and individuals who are intellectually disabled are usually two standard deviations below the average (IQ below 70). Educationally, children with ID are classified into three categories; educable mentally retarded, trainable mentally retarded and severely or profoundly mentally retarded. The "educable" describes those children with IQ scores between 50 and 70, the "trainable," children usually scored between 35 and 49 on IQ tests. Any child scoring between 20 and 34 on the IQ examination was labelled as severely disability and below 20 on IQ tests was labelled profoundly mentally retarded and was considered "untrainable" and "totally dependent". ${ }^{12}$ In this study, a larger sampling size was obtained by taking the suggestions of other studies into consideration, and the study was carried out with 
trainable intellectual disability individuals with IQ scores between 36-49 who needed intensive special education in developing basic academic, daily life, and task skills.

The aim of the study was to evaluate the efficiency of menstruation hygiene training given to trainable intellectual disability adolescent girls.

\section{Materials and Methods}

The study was conducted as a pretest-posttest quasi-experimental research.

\section{Participants}

The universe of the study consisted of trainable intellectual disability adolescent girls attending a Special Education and Application Center (School) located in Ankara province. There were 41 trainable intellectual disability adolescent girls in the related institution. Of the total, 7 were excluded from the study due to not matching the study criteria and another 4 were excluded because their mothers did not give permission. Therefore, a total of 30 participants were involved in the study. The training phase, skill development phase, and the first follow-up phase were completed with 30 participants. In the second follow-up phase, 5 participants were not reached since they had graduated from the school; therefore, the study was completed with 25 participants.

\section{Sampling Inclusion Criteria}

Trainable intellectual disability adolescent girls who ...

- get menstrual cycles,

- have the ability to stick an adhesive object to a surface and remove it from the surface,

- have the ability to dress and undress somebody,

- have the ability to dress and undress oneself,

- have the ability to follow verbal instructions, and

- have the ability to recognize the materials to be used.

\section{Data Collection Forms}

The study data were collected through a "personal information form" and "menstrual skills assessment form". The "personal information form" consisted of participant's nickname (determined by the counselor teacher), age, and class. The "menstrual skills assessment form", used by Richman et al. (1986) in his research, included pad replacement skill steps made up of 18 items. 


\section{Materials}

- A projection device and computer were used for video demonstration.

- Dolls, pads, bags, laundry, trash, and toilet paper were used for skills step.

- Different sizes and colors of materials (dolls, underwear, and pads) were used to increase generalization ability.

\section{Procedure}

The study was conducted in the classroom in the school environment. The application of the study was administered in the following order (Figure 1).

\section{Pretest phase:}

The mothers were informed about the study and their consent about their daughters' participation in the study was obtained. The trainable intellectual disability adolescent girls' pre-training pad replacement skills were evaluated.

2. Application phase: Students were given individual skills development training.

A- Training phase: Instructors introduced themselves to the participants and introduced the dolls and other materials (dolls, pads, toilet rolls, hand towel, and trash) to be used during training. Pad replacement was taught through the use of a video (the necessity of pad use during this term, pad placement, and pad replacement training). The video was watched once for the students.

$B$-Skill development phase: The pad replacement skills form, which was used in the study of Richman et al. (1986), was utilized in this study of skills development phase of this study. Pad replacement skills analysis was administered (Table 1). The researchers shown all steps of pad replacement skills on a model (doll) one by one. Then, they expected the students to do the same on the baby. This process was repeated with the student until the student made all the steps in the correct order, and the student was supported where he forgot and could not. Individual education was given to each student.The same procedure was repeated with each individual. The procedure was repeated between 2 and 8 time for each student. Finally, Finally, the students' pad replacement skill was evaluated with two observers (the nurse from the institution and the counselor teacher) trained by researchers before starting the study. The marking of the pad replacement skill form was made by these two observers for prevent bias. After the skills training, a letter was sent to the parents of the students. In the letter, the steps of the student's ability to replace the pad, what she could do and what she could 
do and could not with help were specified. The parents were asked to support trainable intellectual disability adolescent girls at home for the things she could and could not do with help.

\section{Posttest Phase}

a- First Follow-up: One month after the initial skills and training studies (after waiting for the first menstruation cycle following the baseline), the students were administered the pad replacement skills analysis in the company of the researcher and two observers.

b-Second Follow-up: Six months after the initial skills and training studies, the students were administered the pad replacement skills analysis in the company of the researcher and two observers.

\section{Evaluation}

Pad replacement skills of the female students were observed. The observed steps were getting the pad and the bag, taking the doll to the bathroom, sitting the doll on the chair/table, raising the doll's skirt, lowering the doll's underpants, separating the pad from the pants, folding and wrapping the pad, putting the pad into the bag, throwing the wrapped pad into the trash, cleaning the doll with toilet paper, getting the clean pad, separating the paper on the adhesive surface of the pad, throwing the adhesive paper into the trash, placing the pad on the garment with the adhesive surface facing the garment, dressing the doll's underpants, dressing the doll's skirt/trousers, washing the doll's hands, and drying the doll's hands. These skills were marked in the pad replacement skills form as "achieved ( 2 points)", "achieved with help (1 point)", and "could not achieve (0 points)". The marking of the pad replacement skill form was made by these two observers for prevent bias.

Analysis

Statistical Package for the Social Sciences for Windows 24.0 software package was used for statistical analysis. All analyses of the research were made based on a 95\% confidence level and 5\% type-1 error. For descriptive statistics, median, minimum and maximum values were used, and number and \% values were utilized for categorical variables. In addition, Friedman test was used to evaluate the change in median scores over time in the pad replacement skills analysis and Wilcoxon test with Bonferroni adjustment was used to analyze the difference between the groups. Statistical significance was accepted as $\mathrm{p}<0.05$.

\section{Ethics of the Study}

Ethical approval was obtained from Ankara University Ethics Committee (Date:14.12.2017/No:84328). In addition, the permission of the related institution was obtained. The study was conducted in accordance with 
the principles of Helsinki Declaration 2008. At the outset, the parents were informed about the study and their consent about their daughters' participation in the study was obtained.

\section{Results}

The mean age of the participants in the study was 16.56 (1.00), minimum (min):14 and maximum (max):18. All of them (25 people) were found to get menstrual cycles, and their menstrual period was in the normal cycle.

Table 2 shows the distribution of pre- and post training pad replacement skills of trainable intellectual disability adolescent girls. According to the table, the most accurate pre-training skills of trainable intellectual disability adolescent girls were raising the doll's skirt and lowering the doll's underpants and the correct performance of these skills was found to be at the medium level ( $44.00 \%$ and $44.00 \%$ respectively). The posttraining accuracy of these skills was found to be $96.00 \%$ and $92 \%$ respectively in the first and second followups.

The least achieved pre-training skills of trainable intellectual disability adolescent girls were determined to be cleaning the doll with toilet paper, placing the pad on the garment with the adhesive surface facing the garment, washing the doll's hands, and drying the doll's hands (16.00\%, 20.00\%, 16.00\% and 12.00\% respectively). The post-training accuracy of these skills was $68.00 \%, 76.00 \%, 64.00 \%$, and $64.00 \%$ in the first follow-up and $64.00 \%, 76.00 \%, 76.00 \%$, and 76.00\% in the second follow-up, respectively (Table 2).

The highest achieved pre- and post-training skills of trainable intellectual disability adolescent girls were folding and wrapping the pad, and putting the pad into the bag (pre-training: $24.00 \%, 24.00 \%$; post-training first follow-up: 100.00\%, 100.00\%; and second follow-up 100.00\%, 96.00\%, respectively) (Table 2). The least achieved post-training skill of trainable intellectual disability adolescent girls was cleaning the doll with toilet paper (64.00\%), and the most achieved post-training skill was folding / wrapping the pad (100.00\%).

Pre-training and post-training pad replacement skill analysis and median scores of trainable intellectual disability adolescent girls are given in Table 3. The median score for pre-training pad replacement skill was 16.00 (min: 0- max: 36); it was 36.00 (min: 22- max: 36) in the first follow-up after the training; and 36.00 (min: 24- max: 36) in the second follow-up after the training $\left(\mathrm{p}=0.000 ; \chi^{2}=42.00\right)$. This $\mathrm{p}$-value provides strong evidence against the null and in support of the alternative hypothesis. The difference was found to be between the pre-training and first follow-up following the training $(\mathrm{p}=0.003 ; \mathrm{z}=-4.707)$ and between the pre-training and the second follow-up after the training ( $\mathrm{p}=0.003 ; \mathrm{z}=-4.287$ ) (Table 3). 
Table 1. Task analysis of sanitary pad replacement on a doll

1. Gets the pad and the bag.

2. Takes the doll to the bathroom.

3. Sits the doll on the chair/table.

4. Raises the doll's skirt.

5. Lowers the doll's underpants.

6. Separates the pad from the pants.

7. Folds and wraps the pad.

8. Puts the pad into the bag.

9. Throws the wrapped pad into the trash.

10. Cleans the doll with toilet paper.

11. Gets the clean pad.

12. Separates the paper on the adhesive surface of the pad.

13. Throws the adhesive paper into the trash.

14. Places the pad on the garment with the adhesive surface facing the garment.

15. Dresses the doll's underpants.

16. Dresses the doll's skirt/trousers.

17. Washes the doll's hands.

18. Dries the doll's hands. 


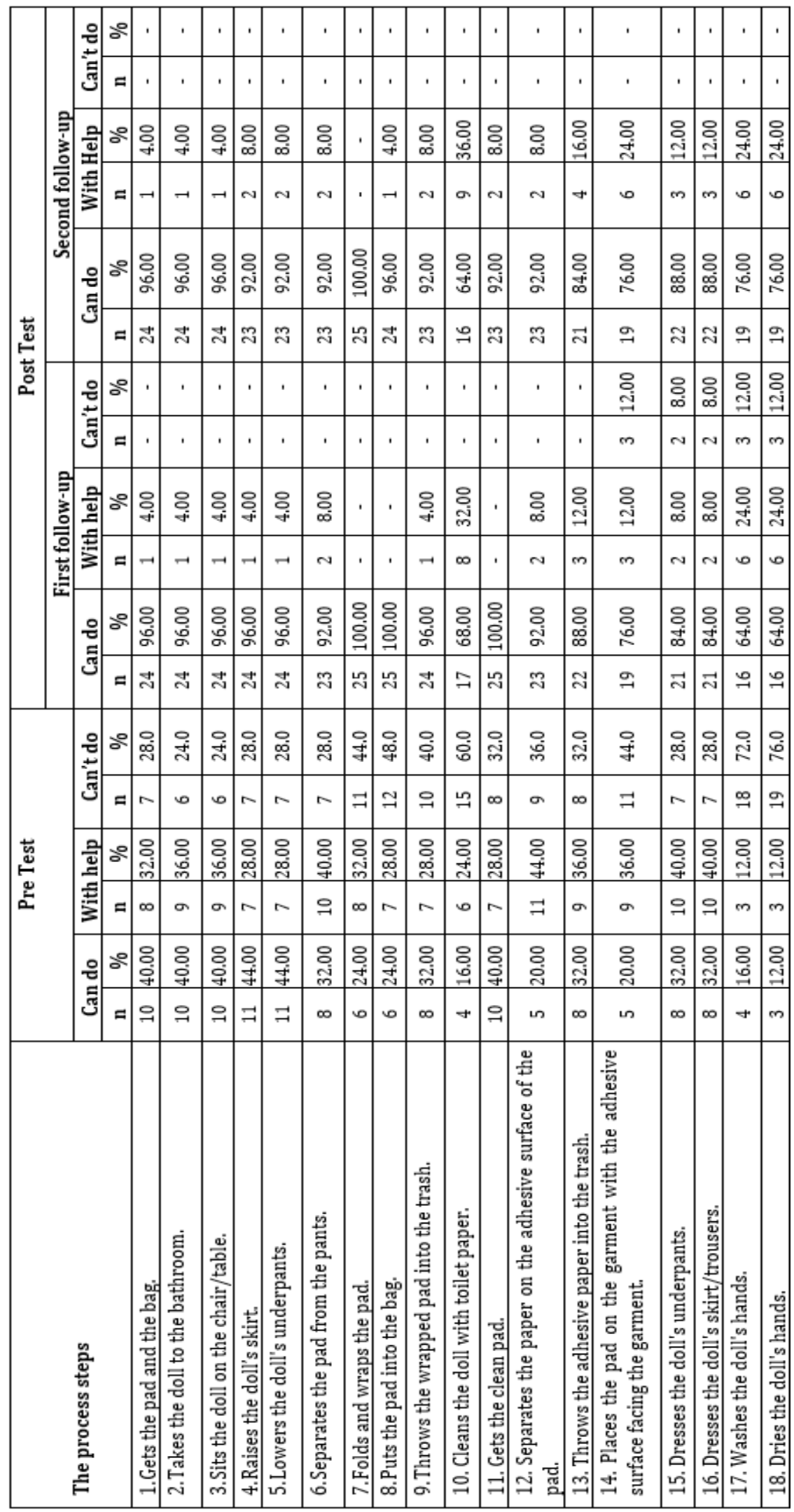

Table 2. The distribution of pre-training and post-training pad replacement skills of educable mentally retarded adolescent girls $(n=25)$ 
Table 3. Pre-training and post-training pad replacement skills analysis and median scores of educable mentally retarded adolescent girls

\begin{tabular}{|c|c|c|c|c|c|c|}
\hline & $\mathbf{n}$ & Median (Min-Max) & $\begin{array}{l}\text { Mean } \\
\text { Rank }\end{array}$ & Analysis* & Intergroup comparison & Analysis ** \\
\hline Pretest & 25 & $16.00(0-36)$ & 1.04 & \multirow{3}{*}{$\begin{array}{c}\chi^{2}=42.00 \\
\mathrm{df}=2 \\
\mathbf{p}=\mathbf{0 . 0 0 0}\end{array}$} & Pretest vs. First follow-up & $\begin{array}{l}z=-4.707 \\
p=\mathbf{0 . 0 0 3}\end{array}$ \\
\hline First follow-up & 25 & $36.00(22-36)$ & 2.36 & & Pretest vs. First follow-up & $\begin{array}{l}\mathrm{Z}=-4.287 \\
\mathbf{p}=\mathbf{0 . 0 0 3}\end{array}$ \\
\hline Second follo & 25 & $36.00(24-36)$ & 2.60 & & $\begin{array}{l}\text { First follow-up vs. Second } \\
\text { follow-up }\end{array}$ & $\begin{array}{l}\mathrm{z}=-1.342 \\
\mathrm{p}=0.540\end{array}$ \\
\hline
\end{tabular}

*Friedman Test

** Wilcoxon test with Bonferroni adjustment

\section{Discussion}

It is known that intellectual disability adolescents have difficulties in the management of menstrual hygiene because their behavioral and physical skills are not sufficient. In many cultures, the help given to these adolescents to manage their menstruation care prevents menstruation from being a special case for each individual. Generally, deficiencies in feelings of shame and secrecy for many intellectual disability adolescents cause them to have negative experiences of menstruation..$^{7,13}$

In addition, menstrual hygiene deficiency affects the daily living standards and causes development of infections. ${ }^{3}$ Therefore, having intellectual disability adolescents gain menstrual care skills is one of the important skills that will prepare them for life and will increase their life quality. In the literature, the studies related to menstruation and intellectual disability adolescents are somewhat limited. ${ }^{7}$ In these studies, menstruation was seen as a major problem and adolescents were found to have negative menstruation experiences. ${ }^{7,}{ }^{14}$ Studies in the United Kingdom and Australia that support women and emphasize their experiences for menstruation management reflect this.7,13,15,16 Education has an important role in reducing these problems.

American College of Obstetrics and Gynecology (2009) reported that intellectual disability adolescents could learn to use pads in the toilet without help. ${ }^{17}$ In this study, intellectual disability adolescents were administered pad replacement skills analysis and they were trained using dolls and video demonstration on the detection of menstrual bleeding, pad replacement, and perineum and hand hygiene. Pre- and post-training pad replacement skills scores were compared, and it was found that the pad replacement skills increased in the first and second follow-ups at the end of the training. There is no study in the literature that uses video and dolls together and evaluates its effectiveness. In their study on 4 intellectual disability participants, Richman and his friends determined that training with dolls were more practical and easier than other methods due to the lack of a need for a special room and ease of application. ${ }^{9}$ Altundağ et al. reported in their study that the training given 
to educable intellectual disability adolescents by using dolls yielded positive results. ${ }^{8}$ Epps et al. (1990) reported in another study that self-generalization findings were at a high level after training on dolls. ${ }^{18}$

In some studies, menstrual care skills training of intellectual disability adolescents has been conducted by creating real-like menstruation conditions (simulations), its generalization to natural environments has been examined, and it has been determined that generalization is achieved. ${ }^{8,9,19}$ Klett \& Turan (2012 (2012) found that, through training, individuals with autism were better informed about the development of the reproductive system, the conditions during the menstruation period (dirty-clean, etc.), the type of pad (wingedwingless, etc.), and that they were able to manage their own independent menstrual care. ${ }^{20}$ In his study on mothers with intellectual disability daughters, Chou (2012) found that mothers' support networks were limited and that daughters developed their own strategies for managing the menstruation period.11 For this reason, it is important to develop the support systems for these families and develop menstrual care skills of their daughters with proper education.

In conclusion, this study has revealed that the education given by nurses to trainable intellectual disability adolescent girls by using video and dolls is an effective method in having intellectual disability adolescents gain sanitary pad replacement skills. Nurses are key persons in improving the reproductive health of intellectual disability individuals. The role of nurses in these training programs will help trainable intellectual disability adolescent girls to access accurate and effective information and will contribute positively to their sexual and reproductive health. For this reason, it is recommended that the awareness of nurses on this issue should be increased and this model of training should be disseminated. Based on the results of this study, it is recommended that nurses working in primary care institutions and nurses working in special education centers should be trained on this training model. In addition, it is suggested that the nurses who receive education be given the opportunity and authority about mentally disabled girls to give this training. This education can be integrated into the education programs and routine health follow-up of these children.

Conflicts of interest: The authors declare no conflict of interest.

Acknowledgements: The authors would like to thank to all participants.

Funding: The authors declared that this study has received no financial support. 


\section{References}

1. Browder DM, Snell ME. Daily living and community skills. In: Instruction of students with severe disabilities, Snell ME (editors). 4th ed., New York, Merrill: Merrill Pub Co; 1993:480-525.

2. Quint EH. Menstrual issues in adolescents with physical and developmental disabilities. Ann N Y Acad Sci 2008;1135:230-6.

3. Çifçi Tekinarslan İ, Eratay E. Investigation of parental behaviour during the period of compliance with adolescents with mental deficiency. E-Journal of New World Sciences Academy 2012;8(3):36374.

4. Kuloglu-Aksaz N, Fırat A. Ergenlik çağındaki özürlü bireylere menstruasyon döneminde gerekli olan temizlik alışkanlıklarının kazandırılması. Ozel Egitim Dergisi 1992;1:37-41.

5. Quint EH, O’Brien RF, AAP The Committee On Adolescence, AAP The North American Society for Pediatric and Adolescent Gynecology. Menstrual Management for Adolescents With Disabilities. Pediatrics 2016;137(4):e20160295.

6. Zacharin M, Savasi I, Grover S. The impact of menstruation in adolescents with disabilities related to cerebral palsy. Arch Dis Child 2010;95(7):526-30.

7. Rodgers J, Lipscombe J. The nature and extent of help given to women with intellectual disabilities to manage menstruation. J Intellect Dev Disabil 2005;30:45-52.

8. Altundağ S, Çakırer Çalbayram N. Teaching menstrual care skills to intellectually disabled female students. J Clin Nurs 2016;25(13-14):1962-8.

9. Richman GS, Ponticas Y, Page TJ, Epps S. Simulation procedures for teaching independent menstrual care to mentally retarded persons. Appl Res Ment Retard 1986;7(1):21-35.

10. Albanese A, Hopper N. Suppression of menstruation in adolescents with severe learning disabilities. Arch Dis Child 2007;92:629-32.

11. Chou YC, Jane Lu ZY. Caring for a daughter with intellectual disabilities in managing menstruation: a mother's perspective. J Intellec Dev Disabil 2012;37:1-10.

12. Adeniyi YC, Omigbodun 00. Effect of a classroom-based intervention on the social skills of pupils with intellectual disability in Southwest Nigeria. Child Adolesc Psychiatry Ment Health 2016;10 (29):1-12.

13. Rodgers J. Pain, shame, blood and doctors: how women with learning difficulties experience menstruation. Womens Stud Int Forum 2001;24(5):523-39.

14. Rodgers J, Lipscombe J, Santer M. Menstrual problems experienced by women with learning disabilities. J Appl Res Intellect Disabil 2006;19:364-73.

15. Carlson G, Wilson J. Menstrual management: the mother's perspective. J Appl Res Intellect Disabil $1994 ; 7(1): 51-63$ 
16. Rodgers J. The experience and management of menstruation for women with learning disabilities. Tizard Learning Disability Review 2001;6(1):35-44.

17. American College of Obstetrics and Gynecology. ACOG Practice Bulletin: No 15: Premenstrual syndrome. Obstet Gynecol 2000;95(4):suppl 1-9.

18. Epps S, Stern RJ, Horner RH. Comparison of simulation training on self and using a doll for teaching generalized menstrual care to women with severe mental retardation. Res Dev Disabil 1990;11(1):37-66.

19. Ersoy G, Tekin İftar E, Kircaali-İftar G. Effects of antecedent prompt and test procedure on teaching simulated menstrual care skills to females with developmental disabilities. Education and Training in Developmental Disabilities 2009;44(1):54-66.

20. Klett LS, Turan Y. Generalized effects of social stories with task analysis for teaching menstrual care to three young girls with autism. Sex Disabil 2012;30(3):319-36. 